\title{
Analysis of inflammatory and metabolic biomarkers in patients submitted to abdominoplasty after bariatric surgery ${ }^{1}$
}

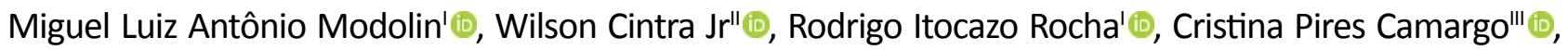

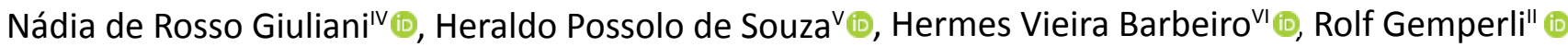

'Assistant Physician, Plastic Surgery and Burns Division, Clinics Hospital, Medical School, Universidade de São Paulo (USP), Brazil. Interpretation of data, statistics analysis, critical revision.

"Full Professor, Plastic Surgery and Burns Division, Clinics Hospital, Medical School, USP, São Paulo-SP, Brazil. Interpretation of data, statistics analysis, critical revision.

I'PhD, Plastic Surgery and Burns Division, Clinics Hospital, Medical School, USP, São Paulo-SP, Brazil. Interpretation of data, statistics analysis, critical revision.

VIntern Physician, Internship in Specialized Complementation, Body Contour Group, Plastic Surgery and Burns Division, Clinics Hospital, Medical School, USP, São Paulo-SP, Brazil. Interpretation of data, statistics analysis, critical revision.

${ }^{\vee}$ Full Professor, Medical Emergencies Discipline, Medical School USP, São Paulo-SP, Brazil. Interpretation of data, statistics analysis, critical revision.

v'PhD in Sciences,Medical School, USP, São Paulo-SP, Brazil. Interpretation of data, statistics analysis, critical revision.

\begin{abstract}
Purpose: To evaluate the serum variations of Interleukins (II) and CPR of abdominoplasties in post-bariatric patients and, to equate the homeostasis (HOMA) from the variations of glycemia and insulin to evolute the metabolic modifications.

Methods: Fourteen women were submitted to abdominoplasties with weight loss after a gastroplasty. Levels of $\mathrm{IL}_{4^{\prime}} \mathrm{IL}_{6}, \mathrm{IL}_{10}, \mathrm{CRP}$, glycemia and insulin were obtained during the preoperative, trans-operative, 24 hours post, $7^{\text {th }}$ and $14^{\text {th }}$ postoperative days.

Results: The $\mathrm{IL}_{4}$ was higher at 24 hours post-surgery, and after a moderate decrease, it remained high until the $14^{\text {th }}$ day. The $\mathrm{IL}_{6}$ and CRP had an expressive increase during the transoperative period. The CRP remained high, and the $\mathrm{IL}_{6}$ decreased on the $7^{\text {th }}$ and $14^{\text {th }}$ days. The $\mathrm{IL}_{10}$ increased during the transoperative period, and it posteriorly decreased to lower levels in comparison to the pre-operative period. The already increased glycemia during the pre-operative period was even higher during the trans-operative and then, returned to preliminary values on the $7^{\text {th }}$ and $14^{\text {th }}$ days after surgery. The HOMA accompanied the insulin. Conclusion: The inflammatory and glycemic serum levels decrease after abdominiplasty in obese post-bariatric patients.
\end{abstract}

Key words: Obesity. Metabolic Syndrome. Interleukins. Homeostasis. Abdominoplasty. 


\section{- Introduction}

Different studies prove that the adipose tissue - subcutaneous and visceral has endocrine activity producing a conjunct of proteins, generically denominated as adipokines. From these adipokines, the cytokines are noted due to inflammatory and anti-inflammatory activities known as interleukins (IL) ${ }^{1,2}$.

These interleukins have their levels increased in obesity, and they are responsible for a chronic inflammatory state stimulating the hepatic production of the C-reactive protein $(\mathrm{CRP})^{3-5}$. Together with the IL6, the CRP promotes an increase of the peripheral resistance to insulin with an eventual diabetes case in predisposing obese patients ${ }^{6-8}$. Hence the reason why obesity is considered an inflammatory and metabolic disease.

Patients with a considerable weight loss and reduction of adiposity, through diet or gastroplasty, have noted changes in inflammatory markers, as the reduction of glycemic levels and decrease of the peripheral insulin resistance ${ }^{9-11}$. Not with standing, few patients with remaining obesity levels present inflammatory activities incipient with variable levels of inflammatory markers ${ }^{12}$, changes of the glycemia and insulin rates and, resulting changes in homeostasis (HOMA) ${ }^{5,6,8}$.

Such patients require the removal of remaining accumulated fat in the dermis resulting from the weight loss, and the abdominoplasty is the most required surgery. In this prospective study, the variations of $\mathrm{IL}_{5}$, CRP, glycemia, insulin, and HOMA are described in moderately obese patients submitted to abdominoplasty in anchor at pre-preoperative, trans-operative and different days of the post-operative and possible modifications in metabolic and inflammatory syndromes. Also, to compare them with studies of other authors.

\section{Methods}

All of them signed the informed consent to participate in the study approved by the Ethics Committee of the Clinics Hospital of the Medical School, Universidade de São Paulo (USP), registration number 48112015.0000.0068. This study was conducted at the Clinics Hospital, Medical School USP without sponsors, therefore, without any conflict of interests.

Fourteen female patients were recruited, all of them were submitted to a malabsorptive-restrictive bariatric surgery by the Capela-Fobi technique, and their demographic composes Table 1.

Table 1 - Demographic data of 14 female patients.

\begin{tabular}{llc}
\hline & $\begin{array}{c}\text { Before } \\
\text { Gastroplasty }\end{array}$ & $\begin{array}{c}\text { Before } \\
\text { Abdominoplasty }\end{array}$ \\
\hline $\begin{array}{l}\text { Age } \\
\text { (years) }\end{array}$ & Mean -42.35 & 45.92 \\
& Minimum - 21 & 29 \\
& Maximum - 58 & 60 \\
& & \\
$\mathrm{BMI}$ & & \\
$\left(\mathrm{Kg} / \mathrm{m}^{2}\right)$ & Mean - 45.63 & 29.62 \\
& Minimum - 35.6 & 21.3 \\
& Maximum - 56.7 & 36.7 \\
\hline
\end{tabular}

All the patients were healthy. They were non-smokers, not under hormone therapy, reposition or contraceptive; they did not use drugs that could alter their behavior. The tests and psychological analyses demonstrated a good psycho-mental balance.

\section{Surgery}

The abdominoplasty was conducted using an incision with an anchor shape, that 
is, one longitudinal axis delimitated by a bidigital clamping since the xiphoid appendix that is found with an inferior cross-sectional fuse containing the lower abdominal fold and extending until the bilaterally superior iliac spines. With the bi-digital clamping maneuver, the superior resection line of this axis is delimitated. After the fat contents of these axes are removed, the musculoaponeurotic plication of the anterior abdominal wall is performed. After the synthesis of the skin and subcutaneous, in three axes, the umbilicus is externalized and fixated in the abdominal skin. The average weight of the exceeding resected adiposity was of $2.068 \mathrm{~kg}$, ranging between $1.000 \mathrm{~kg}$ and $3.600 \mathrm{~kg}$.

\section{Biochemical analyses}

Blood samples were collected in the pre-operative (A), trans-operative (B), and 24 $\mathrm{h}$ after the surgery $(C)$, in the $7^{\text {th }}$ day of the postoperative (D), and $14^{\text {th }}$ of the postoperative period (E). In these samples, $\mathrm{IL}_{4}, \mathrm{IL}_{6}, \mathrm{IL}_{10}, \mathrm{CRP}$, glycemia, and insulin were measured.
The interleukins were analyzed through the immunoassay with Miclipex magnetic beads and MagPix System (Merck Milli Bore USA), and the results were measured in peak values grams/dl.

The C-Reactive Protein G assessed the CRP; through quantitative in vitro immunoturbidimetric CRP assay using the systems Roche/Hitachi cobas c. The values were expressed as $\mathrm{mg} / \mathrm{dl}$.

Glucose was dosed by the Glucose HK Gen.3, in vitro test using the system Roche/ Hitachi cobas $c$. The values were expressed as $\mathrm{mg} / \mathrm{dl}$.

The insulin was analyzed by the electrochemiluminescence immunoassay method (ECLIA) in the analyzer Roche/Hitachi cobas $\mathrm{c}$. The values were expressed as $\mathrm{mg} / \mathrm{dl}$.

The homeostasis was measured following the HOMA equation = Insulin $\mathrm{x}$ Glycemia/22.5.

The parameters were assessed in mean absolute values with a mean of the standard error presented in Table 2.

Table 2 - Results expressed as mean absolute values of the measured parameters and their respective standard errors.

\begin{tabular}{llllll} 
& \multicolumn{1}{c}{$\begin{array}{c}\text { Pre } \\
\text { (mean } \pm \\
\text { standard error } \\
\text { mean) }\end{array}$} & $\begin{array}{c}\text { Trans } \\
\text { (mean } \pm \\
\text { standard error } \\
\text { mean) }\end{array}$ & $\begin{array}{c}\text { 24hPOST } \\
\text { (mean } \pm \\
\text { standard error } \\
\text { mean) }\end{array}$ & $\begin{array}{c}\text { 7dPOST } \\
\text { (mean } \pm \\
\text { standard error } \\
\text { mean) }\end{array}$ & $\begin{array}{c}\text { 14dPOST } \\
\text { (mean } \pm \\
\text { standard error } \\
\text { mean) }\end{array}$ \\
\hline IL-4 & $0.22 \pm 0.4$ & $0.17 \pm 0.01$ & $0.37 \pm 1.0$ & $0.68 \pm 1.2$ & $0.79 \pm 0.1$ \\
IL-6 & $3.66 \pm 13.0$ & $23.5 \pm 1.7$ & $40.43 \pm 0.07$ & $11.2 \pm 8.4$ & $4.53 \pm 0.6$ \\
IL-10 & $6.02 \pm 6.2$ & 4.6 & $11.48 \pm 0.5$ & $6.18 \pm 6.3$ & $4.59 \pm 4.2$ \\
CRP & $3.3 \pm 7.7$ & $1.15 \pm 1.3$ & $47.9 \pm 1.7$ & $27.85 \pm 19.8$ & $17.2 \pm 2.7$ \\
Glycemia & $99.1 \pm 29.1$ & $125.8 \pm 3.8$ & $127.6 \pm 3.9$ & $105.1 \pm 36.1$ & $101 \pm 1.6$ \\
Insulin & $4.1 \pm 3.4$ & $4.25 \pm 0.2$ & $15.8 \pm 1.4$ & $10.2 \pm 12.4$ & $8.4 \pm 0.6$ \\
HOMA & 18.05 & 23.5 & 89.6 & 47.6 & 38.2 \\
\hline
\end{tabular}

\section{Results}

The $\mathrm{IL}_{4}$ levels increased since the first 24 $\mathrm{h}$ after surgery, and they remained high until the $14^{\text {th }}$ postoperative day. The $\mathrm{IL}_{6}$ measures increased in the trans- and $24 \mathrm{~h}$ postoperative, and then dropped in the $7^{\text {th }}$ postoperative day approximating to the initial level on the 
$14^{\text {th }}$ postoperative day; these variations are similar to the $\mathrm{IL}_{10}$ with excretion in the $24 \mathrm{~h}$ postoperative when it presented a decrease. The CRP was considerably higher at 24 hours after surgery and decreased on days $7^{\text {th }}$ and $14^{\text {th }}$ post-surgery.

Glycemia increased in the transoperative and the $24 \mathrm{~h}$ post-surgery, and decrease to normal levels on the $7^{\text {th }}$ and $14^{\text {th }}$ postoperative days. The insulin level behavior followed the linear pattern of the glycemic levels. The relationship between glycemia and insulin presented by HOMA was higher in the trans- and $24 \mathrm{~h}$ postoperative moments, although it continued high in the $7^{\text {th }}$ and $14^{\text {th }}$ postoperative days when compared to the preoperative phase.

\section{- Discussion}

The adipose tissue performs an endocrine activity, producing several proteins as such IL and adipokeins. These proteins play an crucial function in obesity related complications. Most of these complications were associated to paracrine inflammation adipose tissue' role. The inflammation causes metabolic dysfunstions and type 2 diabetes ${ }^{2}$.

In this study, the aim was to identify the modifications in the interleukins $\mathrm{IL}_{4}, \mathrm{I}_{6}$, and $\mathrm{IL}_{10}$. The $\mathrm{IL}_{4}$ is an interleukin produced in the adipose tissue as a result of the interaction with macrophages residing in this tissue and others that flow to it also with the inflammatory exudate after the surgical trauma ${ }^{11,12}$. In the visceral adipose tissue, the $\mathrm{IL}_{4}$ regulates the lipogenesis due to its lipolytic activity. In the subcutaneous adipose tissue, it performs an accentuated anti-inflammatory activity and its variations in levels are associated with the aggression of the abdominoplasty ${ }^{1,3,8}$. Due to its capacity to control lipogenesis and lipolysis, it collaborates to variations in the levels of fatty acids and consequently the deposit of glucose and, as a consequence, the regulatory activity of the insulin sensitivity and variations subsequent of homeostasis ${ }^{13}$. The patients submitted to abdominoplasty had an average BMI of $29.62 \mathrm{Kg} / \mathrm{m}^{2}$; therefore, still obese, with $\mathrm{IL}_{6}$ and CRP moderately higher translating a moderate inflammatory state. In the transoperative period after the resection of the excess abdominal fat, there was a significant increase of the $\mathrm{IL}_{6}$; in the immediate postoperative there was a high increase of the $\mathrm{IL}_{6}$ and CRP sending the neuroendocrine stimuli corresponding to the inflammatory response to trauma. In sequence, on postoperative days $7^{\text {th }}$ and $14^{\text {th }}$, there was a reduction of the $\mathrm{IL}_{6}$ levels accompanied by the reduction of CRP levels, although still high, they proved the continuation of the inflammatory state ${ }^{9}$, considering that in this series, even with the removal of a mean adipose mass of $1.92 \mathrm{~kg}$ and reducing the mean $\mathrm{BMI}$ to $28.76 \mathrm{~kg} / \mathrm{m}^{2}$ corresponding to a medium level of obesity with consonant inflammatory state.

Modifications in the $\mathrm{IL}_{10}$ levels were found in the results. This cytokine is released due to stimuli exercised over the monocyte/ macrophages located in the adipose tissue, and it has anti-inflammatory action ${ }^{1}$. Its profile showed an increase in the pre-operative, as in the studies series, the patients were obese with an evolving inflammatory state. The $\mathrm{IL}_{10}$ level was accentuated in the trans-operative period, in agreement with the consulted literature ${ }^{1,10}$ and as an inference, it can be hypothesized that it had an anti-inflammatory protective biological activity antagonistic to $\mathrm{IL}_{6}$.

Obesity is also a metabolic disease with increases in the glycemic levels and incipient peripheral insulin resistance ${ }^{14}$. This scenario was seen in the studied series since the preoperative and in the trans-operative as a result of the neuroendocrine stimuli with elevated HOMA rates, meaning an increase 
of the peripheral insulin resistance. It is compatible with the inflammatory state caused by the incipient $\mathrm{IL}_{6}$ activity corroborated by the constancy of the elevated CRP levels, despite the increments of $\mathrm{IL}_{4}$ levels, and moderate $\mathrm{IL}_{10}$ levels that are anti-inflammatories ${ }^{15}$.

The analyzed series in the occasion of the abdominoplasty had a mean BMI compared to the moderate level of obesity and the inflammatory markers $\mathrm{IL}_{6}$ and $\mathrm{CRP}$ showed a low inflammatory level, and the postoperative modifications demonstrated an increase of these markers, but overall, of the $\mathrm{IL}_{4}$ andIL $\mathrm{L}_{10}$ anti-inflammatories, also noting that the HOMA still was elevated. However, it should be considered that although operated, the mean BMI of this series continued compatible with the moderate level of obesity. These findings are congruent with findings of other authors ${ }^{1,15}$, although they conducted longer studies.

The limitations of this study were a short-term study, in this first project we only describe the data. However, in the future studies, our group will compare the obese population to a normal weight population submitted to an abdominoplasty procedure.

There for, our results when compared to the literature data ${ }^{1,8,10,11,15}$, showed an improvement in the metabolic syndrome in obese patients submitted to abdominoplasty in anchor.

\section{Conclusion}

This study suggested an improvement in the metabolic syndrome in obese patients submitted to abdominoplasty in anchor.

\section{References}

1. Esposito K, Giovanni G, Scuderi N, Giugliano D. Role of adipokines in the obesity-inflammation relationship: the effect of fat removal. Plast Reconstr Surg.
2006;118(4):1048-57. doi: 10.1097/01. prs.0000232281.49432.ce.

2. Lyon CJ, Law RE, Hsueh WA. Minireview: adiposity, inflammation and atherogenesis. Endocrinology. 2003;144(6):2195-200. doi: 10.1210/en.2003-0285.

3. Castell JV, Gómez-Lechón MJ, David $M$, Hirrano $T$, Kishimoto $T$, Heinrich PC. Recombinant human interleukin-6 (II-6/ BSF/HSF) regulates the synthesis of acute phase proteins in human hepatocytes. FEBS Lett. 1988;232(2):347-50. PMID: 2454206.

4. Visser $M$, Bouter LM, MacQuillan GM, Wener $\mathrm{MH}$, Harris TB. Elevated C-reactive protein levels in overweight and obese adults. JAMA. 1999;282(22):2131-5. PMID: 10591334.

5. Vozarova B, Weyer C, Hanson K, Tataranni PA, Bogardus C, Pratley RE. Circulating Interleukin-6 in relation to adiposity, insulin action, and insulin secretion. Obes Res. 2001;9(7):414-17. doi: 10.1038/ oby.2001.54.

6. Dandona P, Aljada A, Bandyopadhyay A. Inflammation: the link between insulin resistance, obesity and diabetes. Trends Immunol. 2004;25(1):4-7. PMID: 14698276.

7. Wensveen FM, Valentic $S$, Sestan $M$, Wensveen TT, Polic B. The "Big Bang" in obese fat: events initiating obesity-induced adipose tissue inflammation. Eur J Immunol. 2015;45(9):2446-56. doi: 10.1002/ eji.201545502.

8. Rizzo MR, Paolisso G, Grellat R, Barbieri M, Grellat E, Ragno E, Grella R, Nicoletti $G$, D'Andrea F. Is dermolipectomy effective in improving insulin action and lowering inflammatory markers in obese women?. Clin Endocrinol. 2005;63(3):253-8. doi: 10.1111/j.1365-2265.2005.02337.x.

9. Gomez FI, Ortega MG, Alonso AA, Soler IO, Tafalla MAS, Paredes MP, Almela MLL. Obesity, endothelial function and inflammation: the effects of weight loss after bariatric surgery. Nutr Hosp. 2016;33(6):1340-6. doi: 10.20960/nh.793.

10.Chiappetta S, Schaack HM, Wolnerhannsen B, Stier C, Squillante S, Weiner RA. The impact of obesity and metabolic surgery on chronic inflammation. Obes Surg. 2018;28(10):3028-40. doi: 10.1007/s11695018-3320-y.

11.Freitas Jr WR, Oliveira LVF, Perez EA, Ilias 
EJ, Lottenberg CP, Silva AS, Urbano JJ, Oliveira Jr MC, Vieira RP, Ribeiro-Alves M, Alves VLS, Kassab P, Thuler FR, Malheiros CA. Systemic inflammation in severe obese patients undergoing surgery for obesity and weight-related diseases. Obes Surg. 2018;28(7):1931-42. doi: 10.1007/s11695017-3104-9.

12.Sippel CA, Bastin RMA, Giovanella J, Faccin C, Contini V, Dal Bosco SM. Inflammatory processes of obesity. Rev Aten Saúde. 2014;12(42):48-56. doi: 10.13037/rbcs. vol12n42.2310.

13.Tsao CH, Shiau MY, Chuang PH, Chang $\mathrm{YH}$, Hwang J. Interleukin-4 regulates lipid metabolism by inhibiting adipogenesis and promoting lipolysis. J Lipid Res. 2014;55(3):385-97. doi: 10.1194/jlr. M041392.

14.Trayhurn P, Beattie JH. Physiological role of adipose tissue: white adipose tissue as an endocrine and secretory organ. Proc Nutr Soc. 2001;60(3):329-39. PMID: 11681807. 15.Gonzales-Ortiz M, Robles-Cervantes JA, Cárdenas-Camarena L, Bustos-Saldanha $R$, Martinez-Abundis $E$. The Effects of surgically removing subcutaneous fat in the metabolic profile and insulin sensitivity in obese women after large-volume liposuction treatment. Horm Metab Res. 2002;34(8):446-9. doi: 10.1055/s-200233603.

\section{Acknowledgement}

To Full Prof. Dr. Irineu Tadeu Velasco, Discipline of Clinical Emergencies, Department of Medical Clinic, USP, Laboratory Lim51, where the doses presented in this study were conducted.

\section{Correspondence:}

Miguel Luiz Antônio Modolin

Rua Canadá, 89

01436-000 São Paulo - SP Brasil

Tel.: (55 11)99656-5163

miguelmodolin@uol.com.br

Received: Jan 19, 2019

Review: Mar 16, 2019

Accepted: Apr 12, 2019

\section{Conflict of interest: none}

Financial source: none

This is an Open Access article distributed under the terms of the Creative Commons Attribution License, which permits unrestricted use, $\quad$ (cc)) BY

distribution, and reproduction in any medium, provided the original work is properly cited.

${ }^{1}$ Research performed at Plastic Surgery and Burns Division, Clinics Hospital, Medical School, Universidade de São Paulo (USP), Brazil. 